\title{
Sustainable Entrepreneurship in SMEs: The Case of Creative-Industry SMEs in Jambi, Indonesia
}

\author{
Hetty Karunia Tunjungsari ${ }^{1 *}$, Frangky Selamat ${ }^{1}$, Chairy Chairy $^{2}$ \\ ${ }^{1}$ Faculty of Economics and Business, Universitas Tarumanagara, Jakarta 11470, Indonesia \\ ${ }^{2}$ School of Business, President University, Cikarang, West Java 17530, Indonesia \\ *Corresponding author. Email: hetty@fe.untar.ac.id
}

\begin{abstract}
This study aimed to investigate the relationship between motivational factors and the tendency to carry out sustainable entrepreneurship in Small and Medium Enterprises (SMEs). We proposed that there is an effect of sustainable attitude, social norms, and perceived desirability on sustainable entrepreneurship. A sample of 100 SME owners from creative industry in Jambi, Indonesia, participated in the study. Data analysis was performed using multiple regression analysis. This research concluded that there is a significant effect of sustainable attitude, social norms, and perceived desirability on sustainable entrepreneurship among creative-industry SMEs in Jambi. Theoretically, this study is enriching sustainable entrepreneurship research at the SME-level. In practical terms, the implications of this research can be the consideration for government and local policymakers in encouraging sustainable entrepreneurship practices, especially at the SME-level.
\end{abstract}

Keywords: sustainable attitude, social norms, perceived desirability, sustainable entrepreneurship, SMEs, creative-industry

\section{INTRODUCTION}

Sustainable entrepreneurship is an entrepreneurial concept that has received much attention in recent years. This concept arises, because there is a need to run a business that is able to maintain the sustainability of resources in the long-term. The issue of scarcity of resources and efforts to conserve the environment on a large-scale have forced business actors to run their businesses in a more environmentally-friendly manner. However, the concept of sustainable entrepreneurship has not yet reached the level of small and medium-sized enterprises (SMEs). Given that small and medium enterprises are the business groups with the largest population in Indonesia and their locations are scattered throughout the territory of Indonesia, it is certainly important to make special efforts to encourage the adoption of sustainable entrepreneurship practices in this group.

[1] stated that entrepreneurship has made a major contribution to the economic and non-economic development of a nation. Entrepreneurship creates jobs, improves products, creates new businesses, changes people's lives, etc. However, entrepreneurial activities have also caused negative effects, resulting in a decrease in environmental quality. Various environmental problems occur such as global resources scarcity and the use of natural resources that are limited.

Since entrepreneurial activities have contributed to environmental damage, entrepreneurs have played a role in sustainability issues [2] [3] [4]. The efforts to link entrepreneurship with sustainable management have developed a new method called "Sustainable Entrepreneurship" [5] [6]. However, very few studies have been conducted to examine sustainable entrepreneurship practices at the SME-level.

According to [7], work attitude behaviour is an attitude of order in one's feelings and thoughts and a tendency to act on aspects of the environment. According to [8], attitude is a way of placing or carrying oneself, or how to feel, the way of thinking, and behaviour. The results showed that there is a relationship between Sustainable Attitude and Sustainable Entrepreneurship.

There are 3 important points according to [9] in sustainable entrepreneurship, which are:

1. Sustainable entrepreneurship finds and makes innovations to solve problems related to sustainability issues.

2. Sustainable entrepreneurship means getting solutions to the market through creative organizing.

3. Sustainable entrepreneurship is in the process of adding sustainability value by looking at life-support systems.

Thus, sustainable entrepreneurship is an activity to build and run a business with attention to the environment and the sustainability of existing resources to be used both for the present and in the future.

[10] concluded that the optimistic or pessimistic mindset of people may have an effect on their decision to follow sustainable practices. This means that a person's approach to sustainability practices will affect his or her plan to adopt sustainable entrepreneurship. As regards to the effect of social norms on sustainability activities, [11] has found that social pressures have a direct impact on sustainable behavioural intentions. Similarly, [12] and [13] have also 
suggested that the environmental activity of entrepreneurs is the result of other forces.

The goal of this study was to examine the factors that affect sustainable entrepreneurship. The effects of sustainable attitude, social norms, and perceived desirability on sustainable entrepreneurship would be tested in this study. The implications of this study would be further discussed in the discussion section.

\section{BACKGROUND}

\subsection{The Influence of Social Norms on Sustainable Entrepreneurship}

[9] [10] [11] [14] [15] [16] suggested that the sustainable entrepreneurship approach involves a joint SocioEntrepreneurship process and the parties involved in it. Thus, Socio Entrepreneurship does not only support independence, but on the other hand, is also interrelated with one another among the actors in terms of achieving certain goals.

This phenomenon can be seen by recognizing the SocioEntrepreneurship orientation, which emphasizes on processes and actions. Quality is known not on how much the social side is increasing, but on how much the contribution to Socio-Entrepreneurship requires engaging oneself in the process of enhancing the social aspect. The thesis about Socio Entrepreneurship explores entrepreneurship from an economic and social viewpoint. However, other considerations, such as political, cultural and religious aspects, have not been checked. This analysis needs to be carried out in order to enrich the entrepreneurial outlook and become one of the factors that influence society in the European region, the United States, and other regions. So, from the above conclusion, it can be proven that there is an influence of Social Norms on Sustainable Entrepreneurship.

\subsection{The Influence of Perceived Desirability on Sustainable Entrepreneurship}

In order to be successful, an entrepreneur must have social attitudes and norms that can adapt to see the opportunities from surrounding environmental conditions. And in the end, an entrepreneur makes decisions on how to influence someone's life through Perceived Desirability. This is in line with research by [17] which concluded that indirectly social networks affect the interest in entrepreneurship through Perceived Desirability. Entrepreneurship does not only rely on interest, but also on the ability as well. Hence, from the information above, it can be concluded that there is an influence of Perceived Desirability on Sustainable Entrepreneurship. When someone wants to be serious in starting a business, it can affect the support from within him / herself to start Sustainable Entrepreneurship.

\subsection{The Influence of Sustainable Attitude, Social Norms, Perceived Desirability on Sustainable Entrepreneurship}

Based on the conceptual description of Sustainable Entrepreneurship above, it can be said that the main pillar of Sustainable Entrepreneurship is 3P (People, Planet, Profit). According to [18] and [19], these three pillars must be fulfilled first before an entrepreneurial activity can be called sustainable. The first pillar of People concerns on the corporate behaviour in social and ethical issues, for example, how companies treat their employees. Issues that need to be addressed properly are the protection of human rights, fraud prevention and corruption, the use of child labour, gender relations and discrimination, and so on. Planet is the second pillar concerning on the company's impact on natural resources. The existence of environmental regulations and laws has contributed to the integration of the environment into business practices such as the emergence of social norms. Finally, the Profit pillar is not only about the benefit associated with the pure financial results of an enterprise, but also about the use and allocation of added-values for employment, infrastructure investment, and sponsorship of labour distribution and participation. In subsequent developments, [20] argued that in order to maintain the entrepreneurship, entrepreneurs also need to know about the construction of a community (society) in which social norms are included. It is very supportive if social norms become one of the variables in Sustainable Entrepreneurship, whereas social norms characterize the uniqueness of society. Therefore, with the existence of social norm factors, there is already an evidence of a positive correlation to entrepreneurship.

[21] said that intention is related to the style of motion that encourages a person to face or deal with people, objects, activities, experiences stimulated by the activity itself. Based on the explanation about the meaning of desire conveyed from several sources above, it can be concluded that desire is a feeling of interest in something or activity without coercion and feels happy to learn it. This feeling of attraction is not due to compulsion, but it's due to high awareness because of a strong desire to achieve its goals. Based on the above definitions, it can be concluded that there is a significant influence of sustainable attitude, social norms, and perceived desirability towards sustainable entrepreneurship.

[17] and [21] mentioned the role of individual expectations in behavioural intention. The descriptive studies showed that SME managers display optimistic or beneficial attitudes towards industry and care about the social burden of others in terms of their business activities. As for managers' perceptions, they are considered to be sustainable entrepreneurs, attractive, and recognized as having the necessary abilities to become entrepreneurs.

Sustainable perceptions, perceived desirability, and social norms have been shown to have a positive relationship with the participation in sustainable entrepreneurship, and are also significant in motivating SME practitioners to engage in the sustainable entrepreneurship activities. This mindset, 
as supported by previous research, is not only essential for the determination of entrepreneurial intentions [22] [23] [12]. There is also an immediate need to foster a sustainable mindset among the SME participants in the growth of sustainable entrepreneurship. In addition, social norms are also connected to sustainable entrepreneurial behaviour [13] [24] and sustainable attitudes [25] [2]. Therefore, the relationship and interaction among SMEs is essential to encourage more SME owners-managers to engage in sustainable entrepreneurship. Sustainable attitude, social norms, and perceived desirability can be used as predictor variables for the amount of motivation for Sustainable Entrepreneurship. Based on these problems, the research framework can be seen in the following figure:

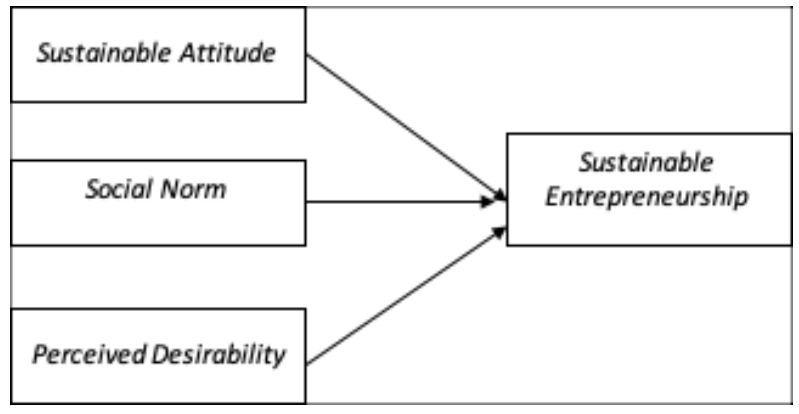

Figure 1 Research Model

This research was conducted to investigate the influence of sustainable attitude, social norms, and perceived desirability. Based on these objectives, the hypotheses in this study are:

$\mathrm{H}_{1}$ : There is an effect of sustainable attitude towards sustainable entrepreneurship.

$\mathrm{H}_{2}$ : There is an effect of social norms on sustainable entrepreneurship.
$\mathrm{H}_{3}$ : There is an effect of perceived desirability on sustainable entrepreneurship.

$\mathrm{H}_{4}$ : There is an effect of sustainable attitude, social norms, and perceived desirability on sustainable entrepreneurship.

\section{METHODS}

The population in this study is Small and Medium Enterprises (SMEs) in Jambi City. We selected 150 participants using the purposive sampling method and below were the criteria such as:

a. Respondents were the SMEs owners in Jambi City.

b. Respondents aged 20 years and above.

c. The business had been running for more than 2 years in 2020 .

The Independent variables in this study are a sustainable attitude, social norms, and perceived desirability, while the dependent variable in this study is sustainable entrepreneurship. This study examines whether there is an effect of independent variables on the dependent variable. A survey was administered from February until June 2020. From the survey, we had collected 124 responses. However, due to the lack of some information in the responses, there were only 100 responses to proceed further. Data analysis was conducted using the multiple regression analysis with SPSS Statistics Software version 23.

\section{RESEARCH RESULTS}

In this study, the results of multiple regression analysis were carried out in Research Model as follows.

Table 1 Regression Analysis Results

\begin{tabular}{|c|c|c|c|c|c|}
\hline \multirow{2}{*}{ Model } & \multicolumn{2}{|c|}{$\begin{array}{c}\text { Unstandardized } \\
\text { Coefficients }\end{array}$} & \multirow{2}{*}{$\begin{array}{c}\begin{array}{c}\text { Standardized } \\
\text { Coefficients }\end{array} \\
\text { Beta }\end{array}$} & \multirow{2}{*}{$\mathrm{T}$} & \multirow{2}{*}{ Sig. } \\
\hline & B & Std Error & & & \\
\hline Constant & 3.878 & 1.518 & & 2.555 & .012 \\
\hline Sustainable Attitude & -.043 & .068 & -.058 & -.635 & .527 \\
\hline Social Norms & .249 & .095 & 247 & 2.636 & .010 \\
\hline Perceived Desirability & .374 & .050 & .588 & 7.444 & .000 \\
\hline
\end{tabular}

Source: Data Analysis using SPSS version 23

Table 1 is the results of multiple regression analysis from Research Model, namely Sustainable Attitude, Social Norms, and Perceived Desirability towards Sustainable Entrepreneurship. Based on Table 1, the regression equation can be formulated as follow:

$\mathrm{SE}=3.878-0.043 \mathrm{SA}+0.249 \mathrm{SN}+0.374 \mathrm{PD}$

The following is an explanation of the regression equation:

a. If sustainable attitude, social norms, and perceived desirability $\left(X_{1}, X_{2}, X_{3}\right)=0$, then the sustainable entrepreneurship $(\mathrm{Y})=3.878$. b. If there is a change in the sustainable attitude $\left(X_{1}\right)$ variable by one unit and the other variables are considered constant, then the sustainable entrepreneurship (Y) will decrease by 0.043 units. However, since data does not support the effect of sustainable attitude on sustainable entrepreneurship, any changes on sustainable attitude will not bring significant effect on sustainable entrepreneurship.

c. If there is a change in the social norms variable $\left(\mathrm{X}_{2}\right)$ by one unit and the other variables are considered constant, then the sustainable entrepreneurship (Y) will increase by 0.249 units. 
d. If there is a change in the perceived desirability $\left(X_{3}\right)$ variable by one unit and the other variables are considered constant, then the sustainable entrepreneurship (Y) will increase by 0.374 units.

From the above equation, it can be concluded that the greatest regression coefficient (b) is the value of point $\mathrm{D}$ on perceived desirability, which is 0.374 units and then is followed by social norms variable of 0.249 units.

The R-Square test aims to measure the proportion or percentage of the total variation of the dependent variable or to measure the contribution of the independent variables to the dependent variable. The R-Square test was carried out on the model below, namely Sustainable Attitude, Social Norms, and Perceived Desirability towards Sustainable Entrepreneurship.

Table 2 R-Square Test

\begin{tabular}{cc}
\hline Model & R-Square \\
\hline 1 & 0.452 \\
\hline Source: Data Analysis using SPSS version 23
\end{tabular}

The value of correlation or relationship (R) between Sustainable Attitude, Social Norms, Perceived Desirability, and Sustainable Entrepreneurship is 0.6723. Table 2 explains that the percentage of the influence of Sustainable Attitude, Social Norms, and Perceived Desirability variables on Sustainable Entrepreneurship, which is called the Coefficient of Determination $\left(\mathrm{R}^{2}\right)$, is $45.2 \%$. Meanwhile, the remaining influence on Sustainable Entrepreneurship is caused by other variables as much as $54.8 \%$.

\section{DISCUSSIONS}

The validity and reliability analysis show that all variables are valid and reliable. It is valid because the corrected-item total-correlation value of all-sentence items on each attribute is greater than 0.2. And because the Cronbach's Alpha is greater than 0.6, it is considered to be valid. This shows that it is feasible to use the questionnaire as a measurement tool for data analysis purpose.

From the description of research subjects, regarding the gender characteristics of the respondents, the females (54\%) are more than males $(46 \%)$. Other majority characteristics of the respondents are having the latest education of senior high school, and earning a monthly income of less than IDR 5 million

The results of the classical assumption analysis show that the multiple regression model can be used to analyze the data, because there is no multicollinearity effect, the heteroscedasticity does not occur, and there is normality of the data.

The findings of the Multiple Regression Analysis for Model 1 , namely $\mathrm{SE}=3.878-0.043 \mathrm{SA}+0.249 \mathrm{SN}+0.374 \mathrm{PD}$ and the result of the Hypothesis Test, indicate that the significance value is 0.000 (less than 0.05 ). It can also be inferred that there is at least one independent variable influencing the dependent variable with a confidence level of $95 \%$. The findings of the hypothesis tests (t-test) indicate that the variables of subjective norms and perceived desirability have a positive impact on sustainable entrepreneurship.

From the results of data analysis above, it is known that the $\mathrm{R}$-square for Model 1 is 0.452 , which means that $45.2 \%$ of the variations in independent variables (sustainable attitude, social norms, and perceived desirability) affect the dependent variable (sustainable entrepreneurship), while the rest $(100 \%-45.2 \%)=54.8 \%$ variations in the dependent variable will be explained by other variables not included in this study. With a contribution of $45.2 \%$, it can be concluded that the higher social norms and perceived desirability of SMEs will increase their positive attitude toward sustainable entrepreneurship.

From the conclusion of the t-test analysis in Model 1, it can be concluded that the variables that can cause positive sustainable entrepreneurship are social norms and perceived desirability. This is because entrepreneurs perceive sustainable entrepreneurship as something that can affect the surrounding environment in entrepreneurial endeavours. When entrepreneurs have an interest in implementing sustainable entrepreneurship that can characterize positive environmental support, they also support in establishing social norms in order to establish a perceived desirability for sustainable entrepreneurship. Regarding this new relationship direction, further research is needed to be conducted.

\section{CONCLUSIONS AND SUGGESTIONS}

From the results and discussions in the previous section, the following conclusions can be drawn as follows:

a. There is no effect of a sustainable attitude towards sustainable entrepreneurship.

b. There is an effect of social norm on sustainable entrepreneurship.

c. There is an effect of perceived desirability on sustainable entrepreneurship.

d. There is a simultaneous effect of sustainable attitude, social norms, and perceived desirability on sustainable entrepreneurship.

Concerning the results of this study, several suggestions may be useful for the company and further research, namely as follows:

a. Future studies can add new independent as well as mediating and moderating variables for the benefit of scientific development of sustainable entrepreneurship for SMEs.

b. Future studies are recommended on examining more SMEs in other areas outside West Jakarta in order to reveal more broadly about the factors that influence sustainable entrepreneurship in Small and Medium Enterprises (SMEs).

c. Researchers suggest that entrepreneurs should pay more attention to the environment in running their business.

d. In collecting data, future researchers should not only use a questionnaire, but also use other methods such as 
interview or observation without being noticed by the respondents in order to reduce response bias.

\section{ACKNOWLEDGMENT}

This work is an outcome of the research grant from The Indonesia Ministry of Research and Technology (Kemenristek - BRIN) for the year 2020.

\section{REFERENCES}

[1] Cohen, B., \& Winn, M.I. (2007). Market Imperfections, Opportunity, and Sustainable Entrepreneruship. Journal of Business Venturing, 22(1), $29-49$.

[2] Hockerts, K., \& Wüstenhagen, R. (2010). Greening Goliaths Versus Emerging Davids: Theorizing about The Role of Incumbents and New Entrants in Sustainable Entrepreneurship. Journal of Business Venturing, 25(5), 481-492.

[3] O’Neil, I., \& Ucbasaran, D. (2011). Sustainable Entrepreneurship and Career Transitions: The Role of Individual Identity. 8th International AGSE Entrepreneurship Research Exchange Conference, 1-4 February 2011, Melbourne, Australia.

[4] Parrish, B.D. (2010). Sustainability-Driven Entrepreneurship: Principles of Organization Design. Journal of Business Venturing, 25(5), 510-523.

[5] Tilley, F., \& Young, W. (2009). Sustainability Entrepreneurs: Could They Be the True Wealth Generators of the Future? Green Management International, 55, 79-92.

[6] Dean, T.J., \& McMullen, J.S. (2007). Toward a Theory of Sustainable Entrepreneurship: Reducing Environmental Degradation through Entrepreneurial Action. Journal of Business Venturing, 22(1), 50-76.

[7] Gitosudarmo, Indriyo dan I Nyoman Sudita. 2008. Perilaku Keorganisasian. Yogyakarta: BPFE

[8] Hornby, A.S. 2010.Oxford Advanced Learner's Dictionary Eighth Edition. Oxford: Oxford University Press

[9] Abrahamsson, A. (2007). Researching Sustainopreneurship - Conditions, Concepts, Approaches, Arenas and Questions: An Invitation to Authentic Sustainability Business Forces. Conference proceedings in $13^{\text {th }}$ International Sustainable
Development Research Conference, June 10-12,2007, Mälardalens Högskola, Västerås.

[10] Chen, C.J., Gregoire, M.B., Arendt, S., Shelley M.C., (2011), College and University Dining Services Administrators' Intention to Adopt Sustainable Practices: Results from US Institutions, International Journal of Sustainability in Higher Education, Vol.12, no. 2 , pp. $145-162$.

[11] Vermeir, I., Verbeke, W., (2008), Sustainable Food Consumption among Young Adults in Belgium: Theory of Planned Behavior and the Role of Confidence and Values, Ecological Economics, Vol. 64, pp. 542-553.

[12] Meek, W.R., Pacheco, D.F., York, J.G., (2010), The Impact of Social Norms on Entrepreneurial Action: Evidence from the Environmental Entrepreneurship Context, Journal of Business Venturing, Vol. 25, No. 5, pp. 493-509.

[13] Yaacob, M.R., (2010), A Preliminary Study of Green Micro-entrepreneurs in Kelantan, Malaysia, International Journal of Business and Management, Vol. 5, no. 3, pp. 81-88.

[14] Green, G., \& Haines, A. (2017). Asset Building \& Community Development. SAGE Publications, Inc. DOI: $10.4135 / 9781483398631$

[15] Ife, J. \& Frank Tesoriero, F. (2014) Community Development: Alternatif Pengembangan Masyarakat di Era Globalisasi. Pustaka Pelajar

[16] Soetomo. 2006. Strategi-strategi Pembangunan Masyarakat. Yogyakarta: Pustaka Pelajar

[17] Linan, F. \& Santos, F. (2007) Does social capital affect entrepreneurial intentions? International Advances in Economic Research, Vol. 13 (4), 443-453

[18] Crals, E., \& Vereeck, L. (2005). The affordability of sustainable entrepreneurship certification for SMEs. International Journal of Sustainable Development and World Ecology - INT J SUSTAIN DEV WORLD ECOL, 12, 173-183.

https://doi.org/10.1080/13504500509469628

[19] Untari, D.T. (2013) Ecopreneurship dalam konsep pembangunan yang berkelanjutan. Proceeding Seminar Nasional \& Call For Papers (SCA-3), Vol 3, No 1.

[20] Shepherd D.A., Patzelt H. (2017) Researching Entrepreneurships' Role in Sustainable Development. In: Trailblazing in Entrepreneurship. Palgrave Macmillan, Cham. https://doi.org/10.1007/978-3-31948701-4_5 
[21] Djaali. 2008. Skala Likert. Jakarta: Pustaka Utama.

[22] Shapero, A., \& Sokol, L. (1982). The Social Dimensions of Entrepreneurship. In C.A. Kent, D.L. Sexton and K.H. Vesper (Eds.), The Encyclopedia of Entrepreneurship (pp. 72-90). Englewood Cliffs, NJ: Prentice-Hall.

[23] Paço, A. M. F., Ferreira J. M., Raposo, M., Rodrigues, R. G., \& Dinis, A. (2011). Behaviours and entrepreneurial intention: Empirical findings about secondary students. Journal of International Entrepreneurship, 9, 20-38.

[24] Fini, R., Grimaldi, R., \& Sobrero, M. 2009. Factors Fostering Academics to Start up New Ventures: An Assessment of Italian Founders' Incentives, Journal of Technology Transfer, forthcoming.

[25] Schwartz, M.S. (2009). Beyond the Bottom Line: A Shifting Paradigm for Business? In J. Friedland (Ed.), Doing Well and Good: The Human Face of the New Capitalism (pp. 131-147). Charlotte, North Carolina: Information Age Publishing.

[26] Moriano, J.A., Gorgievski, M., Laguna, M., Stephan, U., \& Zarafshani, K. (2012). A Cross-cultural Approach to Understanding Entrepreneurial Intention. Journal of Career Development, 39(2), 162-185.

[27] Kautonen, T., Tornikoski, E.T., \& Kibler, E. (2011). Entrepreneurial Intentions in the Third Age: The Impact of Perceived Age Norms. Small business economics, 37(2), 219-234.

[28] Birgelen, M.V., Semeijn, J., \& Keicher, M. (2009). Packaging and Pro-Environmental Consumption Behavior: Investigating Purchase and Disposal Decisions for Beverages. Environment and Behavior, 41(1), 125-146.

[29] Guerrero, M., Rialp, J., \& Urbano, D., 2008. The Impact of Desirability and Feasibility on Entrepreneurial Intentions: A Structural Equation Model. International Entrepreneurship Management Journal, 4, pp. 35-40. 